\title{
Life purpose and sibling care in adolescence: possible associations
}

\author{
Projetos de vida e cuidado entre irmãos na \\ adolescência: possíveis associações
}

\author{
Letícia Lovato DELLAZZANA-ZANON ${ }^{1}$ iD 0000-0003-0649-1675 \\ Cristian ZANON² (D) 0000-0003-3822-5275 \\ Jonathan Richard Henry TUDGE3 ${ }^{3}$ (D) 0000-0003-4242-8067 \\ Lia Beatriz de Lucca FREITAS ${ }^{2}$ (iD) 0000-0002-8854-6512
}

\begin{abstract}
The aim of this study was to investigate the possible relations between sibling care level and the areas of interest in adolescents' life purposes. Participants were 113 adolescents. The instruments were a record of socio-demographic data, the household tasks and Sibling Care Questionnaire, and a written testimony on life purpose. We identified 347 life projects, which were grouped into the following categories: career, family, possessions, happiness, and generosity. The results of the Pearson's correlations indicated positive associations between sibling care and generosity and career. Thus, there is a tendency that adolescents who take care of their younger siblings have more life projects related to assisting the family of origin and to professional development. These results suggest that taking care of younger siblings may influence the areas of interest of adolescents' life purposes.
\end{abstract}

Keywords: Adolescence; Life purpose; Low-income families; Sibling care.

\section{Resumo}

O objetivo deste estudo foi investigar se há relação entre nível de cuidado dos irmãos maiores para com os menores e as áreas de interesse dos projetos de vida de adolescentes. Cento e treze adolescentes participaram do estudo. Para

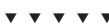

1 Pontifícia Universidade Católica de Campinas (PUC-Campinas), Centro de Ciências da Vida, Programa de Pós-Graduação em Psicologia. Av. John Boyd Dunlop, s/n., Prédio Administrativo CCV, Jardim Ipaussurama, 13060-904, Campinas, SP, Brasil. Correspondence to: L.L. DELLAZZANA-ZANON. E-mail: <leticiadellazzana@gmail.com>.

2 Universidade Federal do Rio Grande do Sul, Instituto de Psicologia, Programa de Pós-Graduação em Psicologia. Porto Alegre, RS, Brasil.

3 University of North Carolina at Greensboro, Department of Human Development and Family Studies. Greensboro, NC, United States. Support: Coordenação de Aperfeiçoamento Pessoal de Nível Superior (Funding Code 001).

Article based on the thesis of L.L. DELLAZZANA-ZANON entitled "Projetos de vida na adolescência: comparação entre adolescentes que cuidam e que não cuidam de seus irmãos menores". Universidade Federal do Rio Grande do Sul, 2014.

How to cite this article

Dellazzana-Zanon, L. L., Zanon, C., Tudge, J. R. H., \& Freitas, L. B. L. (2021). Life purpose and sibling care in adolescence: possible associations. Estudos de Psicologia (Campinas), 38, e200038. https://doi.org/10.1590/1982-0275202138e200038 
a avaliação foram utilizados uma ficha de dados biossociodemográficos, o Questionário de Tarefas Domésticas e de Cuidado entre Irmãos e um depoimento escrito sobre projetos de vida. Computaram-se 347 projetos de vida, os quais foram agrupados nas categorias: carreira, família, bens materiais, felicidade e generosidade. Os resultados das correlações de Pearson indicaram associações positivas entre cuidado e as áreas generosidade e carreira. Dessa forma constatou-se uma tendência de que os adolescentes que cuidam mais de seus irmãos mais novos elaborem mais projetos de vida relacionados a ajudar a família e ao desenvo/vimento profissional. Esses resultados sugerem que cuidar de irmãos menores pode influenciar nas áreas de interesse dos projetos de vida dos adolescentes.

Palavras-chave: Adolescência; Cuidado entre irmãos; Famílias de baixa renda; Projeto de vida.

Since the 1960s, classic psychology authors such as Piaget (1964/2007) and Erikson (1968/1976) have drawn attention to life purpose, pointing out that adolescence is the stage of development in which the individual is most prone to planning his or her future. The empirical attention devoted to life purpose in recent decades has produced an abundant amount of evidence pointing to its potential benefits (Sumner, Burrow, \& Hill, 2018). Results of contemporary research on this subject indicate that adolescents from different contexts and social classes, in fact, build life purpose (Bronk \& Mangan, 2016; Klein \& Arantes, 2016; Miranda \& Alencar 2017; Riter, Dellazzana-Zanon, \& Freitas, 2019; Romero, 2017; Salles \& Alencar, 2018; Silva \& Bomfim, 2019; Silveira, Machado, Zappe, \& Dias, 2015). Studying this theme is important, as the presence of life purpose in adolescence is associated with a series of positive aspects for development (Damon, Menon, \& Bronk, 2003), such as healthier and happier life development (McKnight \& Kashdan, 2009) and involvement and contribution to the community and society (Johnson, Tirrell, Callina, \& Weiner, 2018). Converesely, the absence of life purpose can lead to a series of problems, such as: (a) lack of productivity, (b) difficulty in maintaining stable interpersonal relationships, and (c) a feeling of being adrift (Damon et al., 2003).

As regards to the definition of life purpose, literature-review studies (Dellazzana-Zanon \& Freitas, 2015; Winters, Leite, Pereira, Vieira, \& Dellazzana-Zanon, 2018) have indicated that although there is no consensus on the definition of life purpose in national literature, the definition most used in international literature was proposed by Damon et al. (2003, p. 121), according to which life purpose is "a stable and generalized intention to accomplish something that is at once meaningful to the self and of consequence to the world beyond the self" . However, in line with Sumner et al. (2018), given the ambiguity of this definition as to what is considered "meaningful", and its restriction of life purpose to objectives that are focused "beyond the self", we chose to use a different definition for life purpose that seems be more inclusive. The definition chosen, initially proposed by McKnight and Kashdan (2009, p. 242), describes life purpose as "a central, self-organizing life aim that organizes and stimulates goals, manages behaviors, and provides a sense of meaning". For Sumner et al. (2018), this definition is quite broad: a person's goal can reflect any general aim of life; if it serves to organize daily goals and behaviors, it is central to the person's identity and provides meaning to their life.

Studies carried out in Brazil (D’Aurea-Tardeli, 2008; Felckilcker \& Trevisol, 2016) show that adolescent life purpose encompass three major areas of interest: (a) study, (b) work, and (c) family. Felckilcker and Trevisol (2016), for example, carried out a study whose objective was to investigate how high school students in the Midwest of Santa Catarina understood the role of school and study for the realization of their life purpose. The results of this research indicated that the main life purposes mentioned by the participants were to continue their studies, have a profession and start a family. In addition to these areas, some research also mentions purposes related to the acquisition of material possessions (Miranda \& Alencar, 2017) and quality of life (Paredes \& Pecora, 2004). Regarding the acquisition of material possessions, the study by Miranda and Alencar (2017), for example, showed that the most cited life purposes were related to acquiring, earning, wanting to have or buying goods of a material nature, such as housing. As for quality of life, we can

2 mention the study by Paredes and Pecora on the social representations of adolescents from public 
schools in Cuiabá, in which life purposes regarding happiness and health were categorized as purpose related to quality of life.

There are several ways to experience adolescence (Curtis, 2015; Dahl, Allen, Wilbrecht, \& Suleiman, 2018; Margulis, 2001). According to Margulis, insofar as it is a historically constructed condition, adolescence is experienced in different ways, varying mainly according to adolescents' socioeconomic status, gender and generation. It is known that families of low socioeconomic status have specific settings and modes of functioning (Amazonas, Damasceno, Terto, \& Silva, 2003; Silva, Cunha, Ramos, Pontes, \& Silva, 2018), which influences the way young people in these families experience their adolescence. Among adolescents of low socioeconomic status, there is a specific group of adolescents who care for their younger siblings. This study deals especially with the life purpose of these adolescents.

Care among siblings is considered to be all forms of socialization, training and routine responsibilities that an older sibling - a child or adolescent The aim of this study was to investigate the possible relations between sibling care level and the areas of interest in adolescents' life purposes. Participants were 113 adolescents. The instruments were a record of socio-demographic data, the household tasks and sibling care questionnaire, and a written testimony on life purpose. We identified 347 life projects, which were grouped into the following categories: career, family, possessions, happiness, and generosity. The results of the Pearson's correlations indicated positive associations between sibling care and generosity and career. Thus, there is a tendency that adolescents who take care of their younger siblings have more life projects related to assisting the family of origin and to professional development. These results suggest that taking care of younger siblings may influence the areas of interest of adolescents' life purposes assumes in relation to their younger siblings (Weisner \& Gallimore, 1977). Such activities range from total responsibility for the care of one or more younger siblings to the performance of specific tasks in relation to a younger sibling supervised by an adult or other child. These interactions: (a) are critical to the development of the sibling being cared for and the caregiver, (b) contribute to the general well-being of the family, and (c) are part of the lives of many adolescents in contemporary families (Wikle, Jensen, \& Hoagland, 2018).

It is known that sibling-care situations are more likely to occur in families of low socioeconomic status (Burton, 2007; Goetting, 1986). In addition, research on this topic has shown that there are other determinants for sibling care to happen: (a) high number of children (Ferreira, 1991; Goetting, 1986; Minuchin, Nichols, \& Lee, 2009; Weisner \& Gallimore, 1977), (b) female single-parent family setting (Dellazzana \& Freitas, 2010; Goetting, 1986), (c) lack of alternative caregivers (Dellazzana \& Freitas, 2010; Klassen, Gonzalez, Sullivan, \& Ruiz-Casares, 2020; Maynard, 2019), and (d) when the oldest child is female (Burton, 2007).

In a study about the routine of adolescents who care for their younger siblings, Dellazzana and Freitas (2010) revealed that: (a) the routine of adolescent caregivers is quite different from that of non-caregivers, (b) there are different types of care, (c) in addition to carrying out activities for the care of younger siblings, these adolescents may also perform household tasks, and (d) adolescent caregivers may suffer significant harm in different areas of their lives. Regarding the routine, the results showed that adolescents spend many hours a day taking care of their siblings, and in some situations, performing household tasks. As for the type of care, it was observed that it can be formal, when the older sibling is primarily responsible for the care of his or her younger siblings, or informal, when the parents are responsible (primarily the mother) and the older sibling functions only as a mother's helper in these activities. As for the harm, it was found that, due to the care activities and the performance of household tasks, the adolescent caregivers have a school performance well below that expected for their age and little or no time for leisure activities.

Alternatively, some studies indicate that sibling care can bring benefits to everyone involved in the care situation (Ferreira, 1991; Lordelo \& Carvalho, 1989). In a literature review study on care behavior among 
children, Lordelo and Carvalho concluded that there are positive effects on care among children. For the child who cares, these effects are expressed through the training of important functions for adult life, such as the development of responsibility and cognition. For the child being cared for, the effects are a positive influence on the mother - child relationship, development of autonomy and preparation for relationships with peers. Ferreira's research on siblings who perform sibling care in the absence of their parents showed that sibling caregivers can be considered competent socializing agents, encouraging and facilitating the participation of younger siblings in activities of daily life. Another important result of Ferreira's study was that among all the tasks that the caregiver children perform, the activity in which many of them find great satisfaction is taking care of their younger siblings. Thus, there is good reason to believe that taking care of younger siblings can have positive consequences for everyone involved in the care situation. Examining possible advantages of the care situation with regard to the construction of the life purpose is the main focus of this study. Considering that the adolescent who formally takes care of his younger siblings gives up his individual needs in favor of his siblings' well-being, giving good reason to believe that this care activity influences the areas of interest of life purpose.

Research conducted with families in specific context - poverty and immigration - has drawn attention to two aspects that seem relevant to examine this hypothesis: (a) the expression of solidarity (Amazonas et al., 2003) and (b) an obligation in relation to the family of origin (Fuligni \& Pedersen, 2002; Fuligni, Tseng, \& Lam, 1999; Kiang \& Fuligni, 2009; Stein, Gonzalez, Cupito, Kiang, \& Supple, 2015). The expression of solidarity is found in families of low socioeconomic status, in which, due to the daily need for survival, all members of the family group need to collaborate for their maintenance - that is, of the family as a whole (Amazonas et al., 2003). Thus, the needs of the family are above the personal needs of each of its members. It is in this context of help, in which personal needs and interests are subordinated to the family's priorities, that the situation of formal care between siblings takes place.

According to Fuligni et al. (1999), the obligation in relation to the family of origin refers to the values and expectations that family members have in relation to: (a) the duty to help, respect and support one another and (b) taking into account the family's needs and wishes when making decisions. According to these researchers, the obligation in relation to the family of origin is common among North American adolescents whose families emigrated from Asia or Latin America, families with a collective orientation that emphasizes the responsibilities and duties of each member. Thus, even in a society that emphasizes autonomy and independence, such as the United States, adolescents from families that have collective traditions tend to preserve more the values of their families of origin (Fuligni et al., 1999).

Some ideas about the repercussions of experiencing an awareness of obligation towards the family of origin during adolescence are of special interest for this study: (a) the feeling of obligation towards the family extends into the future, when, for instance, parents can no longer support themselves and when these teenagers - already young adults -, can contribute to the family's income (Fuligni \& Pedersen, 2002) and (b) family duty can really provide the basis for a life purpose awareness, which, in turn, positively permeates other aspects of adolescent development (Kiang \& Fuligni, 2009).

Considering that: (a) adolescence is a fertile period of development for the construction of life purpose, (b) a life purpose can cover different areas of interest, (c) some adolescents from families of low socioeconomic status perform daily care activities for their younger siblings, and (d) adolescent caregivers may have a greater sense of obligation towards the family of origin, and, therefore, are more aware of their life purpose, this study aims to investigate whether there is a relation between level of care and areas of adolescent life purpose. Two hypotheses guide this study: H1 - There is a positive association between the

4 level of care; and $\mathrm{H} 2$ - Life purposes related to the family and to work. 


\section{Method}

\section{Participants}

In this study 113 adolescents participated (61.9\% female). The inclusion criteria were: (a) aged between 14 and 16, (b) being a student in the municipal school system, and (c) living with at least one younger sibling. One participant was excluded from the sample, as her older sister had already participated in the research. The average age of the participants was 14.7 years ( $S D=0.8$ years) and the number of siblings varied between one and nine. Regarding schooling, $4.4 \%$ attended up to fifth grade, $12.4 \%$ attended as far as sixth grade, $38.1 \%$ attended up to seventh grade and $40.7 \%$ attended as far as eighth grade $(4.4 \%$ did not answer). All participants attended municipal schools in Porto Alegre. These schools are attended by adolescents from families of low socioeconomic status, in which sibling care is more common. To participate in the research, adolescents did not necessarily have to be the eldest children of the offspring, as it is not always the first-born who assumes the role of sibling caregiver (Dellazzana \& Freitas, 2010). The selection of participants was carried out according to the convenience criterion and the participation of adolescents was voluntary. The number of participants was calculated using the GPOWER Software for a comparison of means test with a sensitivity of 0.80 .

\section{Instruments}

Record of Socio-Demographic Data: This consisted of identification data, family configuration and schooling. The purpose of this data sheet was to provide a description of the sample.

Household Tasks and Sibling Care Questionnaire: The Household Tasks and Sibling Care Questionnaire was adapted from the Household Responsibilities Questionnaire (Riggio, Valenzuela, \& Weiser, 2010) and aims to measure, in Brazilian adolescents, the sibling-care variables and completion of household tasks (Dellazzana-Zanon, Wichmann, Zanon, \& Freitas, 2019). The process of adapting this scale for use in Brazil indicated evidence of validity and reliability, indicating that the Household Tasks and Sibling Care Questionnaire allows appropriate evaluation of the relation between sibling care and carrying out household tasks properly. Evidence of validity was observed through the use of exploratory factor analysis, which corroborated the internal structure of the theoretically expected two-factor scale. The two factors, related to sibling care and household tasks, had adequate alpha coefficients of 0.75 and 0.69 respectively. The Household Tasks and Sibling Care Questionnaire is a self-report questionnaire consisting of nine items ${ }^{4}$ (four referring to sibling care and five referring to household tasks), answered on a five-point Likert Scale: (1) never, (2) one or two days a week, (3) three or four days a week, (4) five or six days a week, and (5) always.

Written Testimony on Life Purposes - (D'Aurea-Tardeli, 2008): This consists of an open-ended self-report question. Participants were asked to write a testimony based on the following hypothetical situation: "Think about the person you are today. Imagine yourself ten years from now. Describe how you would like your life to be".

Initially, a pilot study was carried out to verify the suitability of the instruments with six adolescents. The schools were contacted to inform them about the study and, given their agreement, an appointment was made to explain the research in detail and organize data collection. Once the interest in participating was confirmed, the principal of each school read and signed the Institution's Consent.

$\boldsymbol{\nabla} \nabla \mathbf{v}$

${ }^{4}$ For the purposes of this study, only the results regarding the sibling care variable are presented. 
In order to select participants who had at least two younger siblings, the researcher asked the schools to authorize their visit to the classes. Thus, the researcher identified the adolescents who met this criterion and delivered the Informed Consent Form so that they and their parents or legal guardians could have it read and signed. A date and time were scheduled for the researcher to go to schools and administer the instruments to the participants. Data collection was carried out, in small groups, during the second semester of 2011, on the school premises. All adolescents received instructions on how to complete the instruments. The average time for groups of students to complete the instruments was 30 minutes. Data were collected in eight municipal schools in Porto Alegre, covering the four regions of the city's municipal school system. The research project was approved by the Research Ethics Committee of Federal University of Rio Grande do Sul (Protocol n 20849).

\section{Data analysis}

The socio-demographic data sheet was used to characterize the sample. The care variable was constructed from the Household Tasks and Sibling Care Questionnaire from the sum of the items referring to the care of younger siblings. To analyze the written testimony, a content analysis was carried out (Laville \& Dionne, 1999). The mixed categorization model was used, through which a priori categories are selected, which can be modified throughout the data exploration process, depending on what the analysis indicates. After defining the analysis categories, two judges worked independently to code the answers: one of the judges read and coded all the answers and the other read and coded $25 \%$ of them. The coding of $25 \%$ of responses by a judge is a procedure adopted in studies that carry out this type of analysis (Tudge, Freitas, O'Brien, \& Mokrova, 2018). The inter-judge reliability was estimated using the Kappa coefficient and the measurements obtained ranged between 0.78 and 1. In order to test the hypotheses of this study, Pearson correlation analyses were performed. This analysis allows us to assess how closely the variables of interest are related. Thus, the presence or absence of life purpose (coded as 0 , when the purpose was not mentioned, or 1 when the purpose was mentioned) was correlated with the level of sibling care.

\section{Results}

In total, 347 life purposes were coded, with several participants mentioning more than one purpose. Based on the content analysis, the purposes were grouped into five categories, which concern the focus of the adolescents' life purposes: (a) career, (b) family, (c) possessions, (d) happiness, and (e) generosity (Table 1). The career category included work (non-specific professional and higher education) and study (purposes related to the completion of high school and higher education). The family category included purposes regarding the family of origin (specifically those related to living close to parents and siblings) and starting a new family (including spouse and children). The category of possessions refers to purpose that mention the acquisition of material possessions (for example, house, car, travel and money), also covering purposes related to being independent and achieving financial stability. The happiness category included purposes related to personal or family happiness. The generosity category refers to purposes related to giving things or helping the family. Purposes that could not be classified in any of the previous categories were coded as other. For example, dating and staying away from drugs. Also included in this category were two participants who did not answer the question about how they imagine their life 10 years from now.

We decided to group study and work in the career category, since research carried out in Brazil on life purposes of adolescents who attend public schools showed that, for these adolescents, study and work are related (Paredes \& Pecora, 2004; Teixeira, 2005). The common theme of this research is that through 
Table 1

Frequency and percentage of areas of interest in participants' life purposes

\begin{tabular}{lcc}
\hline Areas of interest & Frequency & Percentage \\
\hline Career & 102 & 29.39 \\
Family & 66 & 19.02 \\
Possessions & 88 & 25.36 \\
Happiness & 30 & 8.64 \\
Generosity & 30 & 8.64 \\
Other & 31 & 8.95 \\
\hline Total & 347 & 100.00 \\
\hline
\end{tabular}

the continuation of studies (that is, the possibility of higher education), it would be possible to get a better job. Paredes and Pecora, for example, showed that there is a direct relation between study and work, since through study it is possible to have a job that allows participants in life. Furthermore, life purposes regarding study and work have been considered as the means to achieve and guarantee quality of life in the future (Paredes \& Pecora, 2004).

As for purposes in relation to giving things or helping the family, it was decided to allocate them to a category called generosity. These purposes differ from those included in the family category. As defined in previous studies on adolescent life purposes (Felckilcker \& Trevisol, 2016), this category gives priority to purpose related to the starting of a new family. Insofar as it is understood that purposes related to providing things or helping the family of origin refer to a different area of the life purpose, focused on specific actions to do good to its members, it was decided to call it a virtue. According to La Taille (2018), moral virtues are qualities attributed to individuals who are desirable and admired and define a person's character. Generosity - a moral virtue -, is characterized by a willingness to sacrifice one's own interests for the benefit of others. This virtue expresses a respect for the other and the generous subject does not benefit materially from his act, although he may feel pleasure or happiness in being generous. It was decided to name the category as generosity and not solidarity, because solidarity cannot be considered a virtue, as it is characterized by self-interested help. It is understood that the purposes cited by adolescents related to giving things or helping the family in the future are a manifestation of generosity.

To investigate the relation between level of care and areas of interest in life purposes, Pearson correlations were performed. There were positive and small correlations between care and two areas of interest: (a) career and (b) generosity (Table 2). These results suggest that there is a tendency for adolescents who care more for their siblings to develop more life purposes related to generosity and career. There was no association between care and other areas of interest in the adolescents' life purposes.

Table 2

Pearson correlations between sibling care and areas of interest in life purposes

\begin{tabular}{lc}
\hline Areas of interest in life purpose & Care \\
\hline Career & $0.20^{*}$ \\
Family & 0.04 \\
Possessions & 0.12 \\
Happiness & 0.09 \\
Generosity & $0.24^{*}$ \\
\hline
\end{tabular}

Note: ${ }^{*} p<0,05$. 


\section{Discussion}

This study found positive relationships between the level of care and the areas of career life purposes (which includes work and study) and generosity, which suggests that adolescents who care more for their siblings build more life purposes that take into account building a future career and helping the family. This result refutes the first hypothesis of this study that the level of care is associated with life purposes in relation to the family (specifically, starting a new family and living close to the family of origin). On the other hand, this result supports the second hypothesis: sibling care is related to life purposes related to work.

Contrary to what was envisaged, no relation was found between the level of care and purpose related to the starting of a new family. One may believe, from this result, even if engaging in sibling care changes the passage through adolescence (Dellazzana \& Freitas, 2010), that this phenomenon is not associated with life purposes related to the construction of a new family. Different studies on lower- and middle-class adolescents (Riter et al., 2019) have shown that although the formation of a new family remains a desired life purpose, this is no longer a priority in the lives of young people. Due to the demands of contemporary life, starting a family is a purpose that will only be carried out after the completion of other purposes considered more important, such as the completion of studies and the achievement of a stable job. Some purposes, therefore, need to be carried out before others. For example, without prior training it is not possible to get a decent job; by the same token, if the young person has not attained financial independence, there is no way to start a family.

The positive correlation between care level and career purpose is not surprising. In fact, it is known that study and work are crucial areas of life purposes for adolescents from families of low socioeconomic status (Paredes \& Pecora, 2004; Petrini et al., 2012; Teixeira, 2005). For example, Petrini et al.'s (2012) research on people living in poverty, for example, has shown that: (a) having a life purpose is one of the aspects that favor tackling poverty, and (b) planning goals and striving to achieve them is a positive conduct that guides not only the individual's, but also the family's movement out of poverty. As one would expect, for low SES adolescents work is viewed as the organizing feature of their life purpose (Teixeira, 2005); however, when adolescents take care of their siblings and experience the daily difficulty of family survival, investing in their career is even more important. More specifically, the association between level of care and career can (a) be understood as a way of maintaining solidarity and obligation towards the family in the future, and (b) suggests that the participants in this study understood that they needed to work and study (career purpose) to ensure that, in the future, they would continue to take care of their families, no longer through the formal care of younger siblings, but by means of the financial resources they will get through work and study.

The positive association between care and life purposes related to generosity can be understood from the logic of solidarity (Amazonas et al., 2003), typical of low socioeconomic status families. Insofar as they need to take care of their younger siblings to ensure their survival, these adolescents experience daily the practice of placing siblings' priorities above their personal needs. The logic of solidarity is opposed to the logic of individualism, inasmuch as collective values - in this case, the care of younger siblings - are more important than individual ones.

Added to logic of solidarity is another aspect possibly related to the results of this research: the obligation in relation to the family (Kiang \& Fuligni, 2009). The fact that there is a tendency for adolescents who care more for their siblings to have more purpose related to generosity, seems to indicate that there is, in their families, a sense of help, care and mutual respect, typical of the obligation towards the family. Furthermore, the concern to improve the living conditions of their families of origin indicates that their needs are taken into account when the participants think about their life purposes. This suggests that the

8 participants are more aware of their life purposes (Kiang \& Fuligni, 2009). 
Both the logic of solidarity and the obligation towards the family are characteristics of the context in which the participants of this study are situated, both of which seem to influence the construction of their life purpose. In a literature review of life purpose in adolescence, Dellazzana-Zanon and Freitas (2015) concluded that one of the four common aspects found in these articles was the importance of the cultural context for the construction of the life purpose. These studies showed that although life purpose is personal, it is built from the values of a specific culture and a specific historical period. Thus, these results indicate that: (a) life purpose cannot be thought of without considering the adolescent's cultural context and (b) the context in which the sibling-care situation happens has particularities that influence the areas of interest in their life purpose.

The positive association between level of care and generosity suggests that the care of younger siblings can influence the way in which these adolescents build their life purposes. If so, one may believe, in fact, that taking care of younger siblings can bring benefits to everyone involved in the care situation, because: (a) these benefits can reflect on adolescent caregivers, who in the future will be more generous adults, and

(b) the whole family of the caregiver can benefit, since the purpose of these adolescents include helping their siblings and parents in the future. In summary, the adolescent caregiver's family will continue to benefit in the future. This will occur no longer, however, via the care of younger siblings themselves, but through broader generous conduct, expressed through the adolescents' purpose of continuing to help parents and/or siblings in the future, as well as giving them material possessions.

Some research on sibling care has already drawn attention to the fact that sibling care relationships can bring both harm (Dellazzana \& Freitas, 2010) and benefits (Lordelo \& Carvalho, 1989) to those involved in the care situation. Regarding the possible benefits, it is known that they are related to the development of specific personal characteristics, whether of the siblings who care (e.g., cognition and responsibility) or those who are cared for (e.g., autonomy). The results of this study draw attention to the benefits that the level of care can have in relation to the life purpose of adolescents who care for their younger siblings, and help us to think, therefore, about the possible advantages of this type of long-term care. Thus, if adolescent caregivers suffer significant losses in relation to education and leisure in the present (Dellazzana \& Freitas, 2010), on the other hand, there is a tendency, in the future for them to be more generous people, who prioritize in their life purposes well-being and the maintenance of their family of origin. These results suggest, therefore, the fact that adolescents are supportive in the present, taking care of their younger siblings, and placing their well-being above their own, can make a difference in what they strive for in the future.

\section{Final Considerations}

In this study, we investigated whether there is a relation between the level of care of younger siblings and areas of adolescent life purposes. The areas investigated were career (study and work), family (building a new family), possessions, happiness and generosity (helping or giving things to the family of origin). The results indicated that adolescents who care more for their younger siblings construct life purposes more focused on the areas of career and generosity. However, differently than expected, no associations were found between the level of care and life purposes in relation to the construction of a new family.

This study makes contributions both in relation to the theme of sibling care and in terms of the life purpose. Regarding care, the results indicate, in addition to the advantages and disadvantages of experiencing this situation, reported in previous research, that level of care among siblings can play an important role in the construction of the generosity virtue. As for the life purpose, this study draws attention to the fact that there is another area of the life purpose for adolescents of low socioeconomic status, in addition to those described in previous research on this topic: the virtues. Considering the care situation of younger 
siblings and the characteristics of the sample, the results of this study indicate that the virtue in question is generosity. It is possible, however, to question: what other specific conditions for experiencing adolescence could stimulate the development of virtues?

Some limitations of this study are related to the sample and the design used. The sample is not representative, which does not allow generalizing the results found. As it is a correlational design, it cannot be said that there is a cause and effect relationship between the level of care and areas of the life purpose. Furthermore, although the instrument used was helpful to investigate how participants imagine themselves in ten years, it is a single self-report question, which does not allow access to the motivations underlying each of the purposes cited by the participants. It is also noteworthy that the correlations obtained are of small magnitude - which indicates little overlap of variance among the variables studied. Considering this limitation and the breadth of the life-purpose construct, we suggest that qualitative studies should be carried out in order to verify: (a) whether the justifications in relation to the other areas of the life purpose can reveal characteristics of the generosity or other virtues, and (b) whether or not the results of this research will be corroborated.

\section{Contributors}

L. L. DELLAZZANA-ZANON wrote the research project that originated the article, collected the data, interpreted the results and wrote the article. C. ZANON performed the statistical analysis and participated in the writing and review of the article. J. R. H. TUDGE was responsible for the final writing (revision and editing) of the article. L. B. L FREITAS was responsible for guiding the research project that originated the article, interpreting the results and writing the article. All authors reviewed and approved the final version of the manuscript.

\section{References}

Amazonas, M. C. L. A., Damasceno, P. R., Terto L. M. S., \& Silva, R. R. da (2003). Arranjos familiares de crianças das camadas populares. Psicologia em Estudo, 8, 11-20.

Bronk, K. C., \& Mangan, S. (2016). Strategies for cultivating purpose among adolescents in clinical settings. In P. Russo-Netzer, S. E. Schulenberg, \& A. Batthyany (Eds.), Clinical perspectives on meaning: positive and existential psychotherapy (pp. 407-421). Cham: Springer International Publishing. https://doi.org/10.1007/978-3-319-41397-6_20

Burton, L. (2007). Childhood adultification in economically disadvantaged families: a conceptual model. Family Relations, 56, 329-345.

Curtis, A. C. (2015). Defining adolescence. Journal of Adolescent and Family Health, 7(2), 27-47.

D’Aurea-Tardeli, D. (2008). A manifestação da solidariedade em adolescentes: um estudo sobre a personalidade moral. Psicologia Ciência e Profissão, 28(2), 208-303.

Damon, W., Menon, J., \& Bronk, K. C. (2003). The development of purpose during adolescence. Applied Development Science, 7(3), 119-128.

Dahl, R. E., Allen, N. B., Wilbrecht, L., \& Suleiman, A. B. (2018). Importance of investing in adolescence from a developmental science perspective. Nature, 554, 441-450. https://doi.org/10.1038/nature25770

Dellazzana, L. L., \& Freitas, L. B. L. (2010). Um dia na vida de irmãos que cuidam de irmãos. Psicologia: Teoria e Pesquisa, 26(4), 595-603.

Dellazzana-Zanon, L. L., \& Freitas (2015). Uma revisão de literatura sobre a definição de projeto de vida na adolescência. Interação em Psicologia, 19(2), 281-292. https://doi.org/10.5380/psi.v19i2.35218

Dellazzana-Zanon, L. L., Wichmann, F., Zanon, C., \& Freitas, L. B. L. (2019). Questionário de tarefas domésticas e de cuidado entre irmãos: avaliando adolescentes em situação de invisibilidade e vulnerabilidade social. In C. R. Campos \& T. C. Nakano (Eds.), Avaliação psicológica direcionada a populações específicas: técnicas, métodos e estratégias (Vol. 1, pp. 165-180). São Paulo: Vetor.

Erikson, E. H. (1976). Identidade, juventude e crise. Rio de Janeiro: Zahar. (Originalmente publicado em 1968). 
Felckilcker, J. B., \& Trevisol, M. T. C. (2016). Ensino médio e os projetos de vida dos adolescentes da região meio oeste catarinense. Unoesc and Ciência, 7(1), 39-46.

Ferreira, E. A. P. (1991). Irmãos que cuidam de irmãos na ausência dos pais: um estudo sobre desempenho em tarefas domésticas e interação ente irmãos (Tese de doutorado não-publicada). Universidade de Brasília, Brasília.

Fuligni, A. J., \& Pedersen, S. (2002). Family obligation and the transition to young adulthood. Developmental Psychology, 38(5), 856-868.

Fuligni, A. J., Tseng, V., \& Lam, M. (1999). Attitudes toward family obligations among American adolescents with Asian, Latin American, and European backgrounds. Child Development, 70(4), 1030-1044.

Goetting, A. (1986). The developmental tasks of siblingship over the life cycle. Journal of Family and Marriage, 48, $403-412$.

Johnson, S. K., Tirrell, J. M., Callina, K. S., \& Weiner, M. B. (2018). Configurations of young peoples' important life goals and their associations with thriving. Research in Human Development, 15(2), 139-166. https://doi.org/10.1080/154 27609.2018.1441576

Kiang, L., \& Fuligni, A. J. (2009). Ethnic identity and family processes in adolescents with Latin American, Asian, and European backgrounds. Journal of Youth and Adolescence, 38, 228-241.

Klassen, C. L., Gonzalez, E., Sullivan, R., \& Ruiz-Casares, M. (2020). I'm just asking you to keep an ear out': parents' and children's perspectives on caregiving and community support in the context of migration to Canada. Journal of Ethnic and Migration Studies, 1-19. https://doi.org/10.1080/1369183X.2019.1707647

Klein, A. M., \& Arantes, V. A. (2016). Projetos de vida de jovens estudantes do Ensino Médio e a escola. Educação e Realidade, 41, 135-154. https://doi.org/10.1590/2175-623656117

La Taille, Y. de (2018). Toward a psychological study of the virtues. In J. R. H. Tudge \& L. B. L. Freitas (Eds.), Developing gratitude in children and adolescents (pp. 25-41). Cambridge: Cambridge University Press.

Laville, C., \& Dionne, J. (1999). A construção do saber: manual de metodologia da pesquisa em ciências humanas. Porto Alegre: Artmed.

Lordelo, E. R., \& Carvalho, A. M. A. (1989). Comportamento de cuidado entre crianças: uma revisão. Psicologia: Teoria e Pesquisa, 5, 1-19.

Margulis, M. (2001). Juventud: una aproximación conceptual. In S. D. Burak (Org.), Adolescencia y juventud en américa latina (pp. 41-56). Cartago: Libro Universitário Regional.

Maynard, A. E. (2019). The sibling relationship in ecocultural context. In: T. Tulviste, D. L. Best, \& J. L. Gibbons (Eds.), Children's social worlds in cultural context (pp. 149-160). Cham: Springer.

McKnight, P. E., \& Kashdan, T. B. (2009). Purpose in life as a system that creates and sustains health and well-being: an integrative, testable theory. Review of General Psychology, 13, 242-251. http://dx.doi.org/ 10.1037/a0017152

Minuchin, S., Nichols, M. P., \& Lee, W. (2009). Famílias e casais: do sintoma ao sistema. Porto Alegre: Artmed.

Miranda, F. H. F., \& Alencar, H. M. (2017). Projetos de vida na adolescência: um estudo na área da ética e da moralidade. Diaphora, 15(2), 27-33.

Paredes, E. C., \& Pecora, A. R. (2004). Questionando o futuro: as representações sociais de jovens estudantes. Psicologia: Teoria e Prática, 6,49-65.

Petrini, G., Alcântara, M. A. R., Moreira, L. V. C., Reis, L. P. C., Fonseca, R. S. S., \& Dias, M. C. (2012). Família, capital humano e pobreza: entre estratégias de sobrevivência e projetos de vida. Memorandum, 22, 165-186.

Piaget, J. (2007). Seis estudos de psicologia (24a ed.). Rio de Janeiro: Forense Universitária (Originalmente publicado em 1964).

Riggio, H. R., Valenzuela, A, M., \& Weiser, D. A. (2010). Household responsibilities in the family of origin: relations with self-efficacy in young adulthood. Personality and Individual Differences, 48, 568-573.

Riter, H. S., Dellazzana-Zanon, L. L., \& Freitas, L. B. L. (2019). Projetos de vida de adolescentes de nível socioeconômico baixo quanto aos relacionamentos afetivos. Revista da SPAGESP, 20(1), 55-68.

Romero, T. B. (2017). Proyecto de vida de jóvenes en el sistema de protección colombiano: una perspectiva desde las intervenciones socioeducativas. Metamorfosis: Revista del Centro Reina Sofía sobre Adolescencia y Juventud, 6, 28-47.

Salles, A. M. B., \& Alencar, H. M. (2018). Projetos de vida e moralidade em adolescentes com indícios de altas habilidades/ superdotação. Revista de Psicología, 36(2), 491-524.

Silva, D. L., \& Bomfim, Z. A. C. (2019). Relações entre a estima de lugar e a construção dos projetos de vida de jovens adolescentes de escolas públicas de Fortaleza/CE: um estudo. Pesquisas e Práticas Psicossociais, 14(1), 1-20. 
Silva, I. C. P., Cunha, K. C., Ramos, E. M. L. S., Pontes, F. A. R., \& Silva, S. S. C. (2018). Estresse parental em famílias pobres. Psicologia em Estudo, 24, 1-17. https://doi.org/10.4025/psicolestud.v24i0.40285

Silveira, K. S. S., Machado, J. C., Zappe, J. G., \& Dias, A. C. G. (2015). Projetos futuros de adolescentes privados de liberdade: implicações para o processo socioeducativo. Psicologia: Teoria e Prática, 17(2), 52-63. https://doi.org/10.15348/19806906/psicologia.v17n2p52-63

Stein, G., Gonzalez, L., Cupito, A., Kiang, L., \& Supple, A. J. (2015). The protective role of familism in the lives of Latino adolescents. Journal of Family Issues, 36(10), 1255-1273. https://doi.org/10.1177/0192513X13502480

Sumner, R., Burrow, A. L., \& Hill, P. L. (2018). The development of purpose in life among adolescents who experience marginalization: potential opportunities and obstacles. American Psychologist, 73(6), 740-752. https://doi.org/10.1037/ amp0000249

Teixeira, E. J. (2005). Juventude pobre, participação e redes de sociabilidade na construção do projeto de vida (Tese de doutorado não-publicada). Universidade Federal do Rio de Janeiro, Rio de Janeiro.

Tudge, J. R. H., Freitas, L. B. L., O'Brien, L. T., \& Mokrova, I. L. (2018). Methods for studying the virtue of gratitude crossculturally. Cross-Cultural Research, 52, 19-30. https://doi.org/10.1177/1069397117737017

Weisner, T. S., \& Gallimore, R. (1977). My brother's keeper: child and sibling caretaking. Current Anthropology, 18(2), 169-190.

Wikle, J. S., Jensen, A., C., \& Hoagland, A. M. (2018). Adolescent caretaking of younger siblings. Social Science Research, 71, 72-84. https://doi.org/10.1037/amp000024910.1016/j.ssresearch.2017.12.007

Winters, C., Leite, J. P. C., Pereira, B. C., Vieira, G. P., \& Dellazzana-Zanon, L. L. (2018). Desenvolvimento juvenil positivo e projetos de vida: uma revisão sistemática da literatura internacional. Cadernos de Educação, 17(35), 39-54.

Received: March 17, 2020

Final version: September 4, 2020

Approved: October 21, 2020 